\title{
Előszó a Sokszínű digitális kultúra tematikus számhoz
}

\author{
Lénárd András \\ Eötvös Loránd Tudományos Egyetem Tanitó- és Óvóképzö Kar Digitális Pedagógia Tanszék
}

A Gyermeknevelés Tudományos Folyóirat digitális pedagógiával foglalkozó tematikus számának gondolata már évekkel ezelőtt felmerült bennünk. Szerettük volna bemutatni a pedagógia ezen fiatal ágának kutatási eredményeit, megközelítésmódjait, illetve rávilágítani a neveléstudomány kora gyermekkorral foglalkozó területei közötti létjogosultságára.

2020 elején azonban, előre meg nem jósolhatóan, a COVID-19 járvány okán más szempontból ugyan, de mind a szakemberek, mind a laikusok érdeklődésének is középpontjába került a digitális pedagógia egyik részterülete, a digitális oktatás. Különszámunk nem kizárólag a digitális oktatással foglalkozik, ám ez a terület fontos aktualitásként jelenik meg a tanulmányok között.

A járvány, a közoktatás, valamint a felsőoktatás területén létrejött helyzet is megmutatta, hogy a pedagógia, azon belül is az egyes módszertanok, illetve a digitális oktatás didaktikája, a digitális környezet ideglélektani vonatkozásainak vizsgálata olyan területek, melyek további kutatásokat kívánnak. Ugyanis már a távolléti oktatás bevezetésének első pillanataiban kiderült: az oktatóknak és a köznevelésben dolgozó pedagógusoknak nem kizárólag technikai-technológiai természetű segítségre van szükségük. A közösségi médiát és a szakmai portálokat szinte azonnal elárasztották a különböző platformokat, alkalmazásokat bemutató, összehasonlító posztok, ismertetők, tutorialok és tanulmányok. Igen kevesen beszéltek és beszélnek azonban a gyerekeket ért hatásokról, a kisgyermekek speciális szükségleteinek és a digitális oktatás vagy a közösségi média kapcsolatáról. A technológia megelőzte az alkalmazásához szükséges módszertani szempontokat, melyek nélkül a digitális oktatás sem érheti el a kellő hatást, illetve akár káros tényezőként is hathat a személyiségfejlődés folyamatában.

Különszámunkat éppen ezért főként neveléstudományi megközelítésnek szánjuk és a kisgyermekkorra fókuszálva igyekeztünk azokat a részterületeket, az ezeken a területeken folytatott kutatásokat bemutatni, melyek középpontjában nem a technológia, hanem az ember, a technológiával közvetlen vagy közvetett kapcsolatba kerülö kisgyermek áll.

Igyekezetünk egyensúlyt találni az elmélet és a gyakorlat között, szerzőink elismert kutatók, digitális tananyagfejlesztők, innovatív gyakorló peda- 
gógusok, akik közvetlen szakterületeik legjavát adták a most megjelenő kiadványunkhoz. A digitalizáció következtében végbemenő agyi folyamatoktól, az információs társadalom és a gyermeki szükségletek kapcsolatán át a gyakorlati alkalmazásokon keresztül vizsgálják szerzőink, milyen válaszokat kell adnia a neveléstudománynak a digitalizáció kihívásaira egy olyan korosztály esetén, melyre még néhány évvel ezelőtt is úgy tekintettek, hogy nem, vagy csak közvetve lesznek jelen a digitális környezetünkben.

Szerzőink nagy gonddal, lelkesen és mély szakmai tudással végezték kutatásaikat, hozták létre pedagógiai innovációikat és készítették el tanulmányaikat, melyek olvasásához, feldolgozásához, hivatkozásához sok sikert és örömöt kívánok:

Lénárd András, a szám vendégszerkesztője

Lénárd András: https://orcid.org/0000-0003-3467-9456 